\title{
Umbilical Cord Serum
}

National Cancer Institute

\section{Source}

National Cancer Institute. Umbilical Cord Serum. NCI Thesaurus. Code C119550.

The clear portion of the blood that remains after the removal of the blood cells and the clotting proteins from umbilical cord blood. 